\title{
Teacher Performance Improvement through Development of Organizational Culture, Work-Discipline, and Job Satisfaction
}

\author{
Muljadi*, Hadhienata S, Adhie E Yusuf \\ Pakuan University Bogor Indonesia
}

*Corresponding Author: Muljadi, Pakuan University Bogor Indonesia

\begin{abstract}
This study aims to find out how teacher performance can be improved by examining the relationship between organizational culture, work discipline and job satisfaction on teacher performance. The sample chosen amounted to 244 people with the criteria of a Private High School teacher in South Tangerang Regency. This study uses Mixed Method Sequential Explanatory, namely the first research uses quantitative methods and then the second one is to deepen the research using qualitative methods. Further, Scientific Identification Theory of Operation Research in Education Management (SITOREM) is used to rank the improvement needed. The results of the study show that (1). There is a positive relationship between Organizational Culture and Teacher Performance with a correlation coefficient of $r_{y l}=0.328$ or $32.8 \%$ (2). There is a positive relationship between Work Discipline and Teacher Performance with a correlation coefficient of $r_{y 2}=0.796$ or $79.6 \%$ (3) There is a positive relationship between Job Satisfaction and Teacher Performance with a correlation coefficient of $r_{y 3}=0.799$ or $79.9 \%$, (4) There is a relationship between Organizational Culture, and Job Satisfaction together with Teacher Performance, indicated by the correlation coefficient $r_{y 1230.555}=$ or $55.5 \%$.
\end{abstract}

Keywords: Organizational Culture, Work-Discipline, Job Satisfaction, and Teacher Performance.

\section{INTRODUCTION}

A teacher is one of the determinants of the high and low quality of education, so every effort to improve the quality of education needs to pay great attention to improving teacher performance. Teachers are required to have a performance that can provide and realize the hopes and desires of all parties, especially the general public who have trusted the school and the teacher in fostering their students. To achieve a good quality education is strongly influenced by the performance of teachers in carrying out their duties, so that teacher performance becomes an essential demand for achieving educational success. The performance of a teacher is related to all activities shown by the teacher in carrying out their duties in class and outside the classroom, as well as people who carry out the mandate and responsibility to educate, teach, guide, direct, and guide students towards mentalspiritual maturity.

Job satisfaction is one of the most critical factors to get optimal work results when a person feels satisfaction in working he will try as much as possible with all his abilities to complete his work assignments with optimal work results. Job satisfaction is something individual because each has a different level of satisfaction according to the value system that applies to him. Job satisfaction is an evaluation that describes someone for feeling happy or unhappy, satisfied or not satisfied at work.

The low work performance of teachers can be known based on observations in the field. To strengthen the temporary data, researchers conducted a preliminary survey of 30 private high school permanent teachers from 6 schools in the city of South Tangerang on February 1-3, 2017 the teacher concerned was assessed by the principal, obtained results and information on the problem of the tendency of the teacher's work performance to below. Based on preliminary studies obtained some info collected from teacher performance assessments conducted by school principals and school supervisors in the South Tangerang City Education Office in 2016 on private high school teachers found that private teachers in the South Tangerang City area were mostly below standard performance.

Based on the description of problem identification and problem boundaries, the formula proposed is as follows: 
Teacher Performance Improvement through Development of Organizational Culture, Work-Discipline, and Job Satisfaction

1. Is there a relationship between Organizational Culture and a teacher's performance?

2. Is there a relationship between work discipline and teacher's performance?

3. Is there a relationship between job satisfaction and teacher's performance?

4. Is there a relationship between organizational culture, work discipline, and job satisfaction together with teacher 'sperformance?

\section{LITERATURE REVIEW}

According to Olina (2004), performance is the result of activity, with the criteria of whether the results can be said to be efficient and effective. Which affects performance is work productivity (comparison between input and output), work effectiveness (level of achievement of goals), achievement indicated by work rank.

Bolkan (2016), Performance is some behaviors and contributions of organizational members to achieve organizational goals. Performance is related to work results. Performance is likened to the results of tests on students, and there are those who score high, low, medium and average. The results of this test show the results of the work done by teachers and students. Factors that influence performance are task performance (the results of work on a given task), citizenship behavior (free individual behavior that is indirectly recognized by the formal system), counter-/productive behavior (behavior that harms the organization).

According to Schein (2010), organizational culture is a pattern of underlying assumptions, which are formed, materialized and developed by organizational members to overcome adaptation problems to external factors and to integrate internal organizational factors - measured through the Behavior Dimension and Work Results, with factors: a. Methods, Art and Technology at work, b. Real behavior patterns, Dimensions of Values: a. The values of the environment, b. Norms agreed upon by members, Dimensions of the Basic Assumption Pattern: a. Relations with the environment, b. Views of humanity, c. Relationships between individuals.

Alveson (2012) state that Organizational culture is an understanding of the values and norms that are important in the organization, which directs the behavior of organizational members. Factors that influence organizational culture are patterns of real behavior of members of the organization, norms, and standards of behavior in work, the most important values (dominant) that are understood together, regulations that become guidelines for members and organizational climate, namely the atmosphere felt by members in life in the organization.

Sofyan (2016) defines work-discipline as an effort to prevent the emergence of negative behavior, and apply penalties for behavior undesirable. The factors that influence work discipline are the rules for control in work and behavior, communication of discipline rules for employees, assessment of employee behavior based on disciplinary regulations, systems and procedures for applying reprimand and sanctions for disciplinary violations.

Suwati (2016) states that work discipline is efforts (provisions) that regulate what behavior can and should not be done by employees. Factors that influence work discipline are rules that set reprimand and sanctions for work behavior that are not desired by the organization, procedures to provide positive reinforcement to behaviors that change due to disciplinary reprimand.

Griffin (2010) argues that job satisfaction is an assessment of workers about how far the overall work satisfies their needs. Job satisfaction is also a general attitude which is the result of several particular traits for work factors, adjustment, and personal social relations outside work. Job satisfaction is basically a security feeling and has the following factors: a) socio-economic factors concerning salaries and social security; b) justice in obtaining social psychological factors such as opportunities to advance, opportunities to get awards, harmonious relationships between colleagues or supervisors; c) position, rank / position, age, financial security, and quality of supervision.

Of the four variables studied, namely Organizational Culture, Work-Discipline, and Job Satisfaction and Teacher Performance, the following hypotheses are arranged;

a. There is a positive relationship between Organizational Culture and teacher performance. 
Teacher Performance Improvement through Development of Organizational Culture, Work-Discipline, and Job Satisfaction

b. There is a positive relationship between work discipline and teacher performance.

c. There is a positive relationship between job satisfaction and teacher performance.

d. There is a positive relationship between organizational culture, work discipline, and job satisfaction together with teacher performance.

\section{METHOD}

This research carried out limited to private high school teachers in South Tangerang City. This research was conducted at the State High School (SMA) in South Tangerang City in the province of Banten. This study uses a research method with a combination of designs sequential explanatory. According to Terrel (2012), the research method is a combination of designs subsequent explanatory is a combination research method that combines research methods quantitative and qualitative sequentially, wherein the first stage the research was carried out using quantitative methods and in the second stage carried out by qualitative methods.

Data needed for research can be drawn from the research sample, and what is learned from the research sample, the results can apply to the population. Some permanent teachers at the private school foundations in South Tangerang in Banten Province as many as 622 people. Using the Slovin formula number in this study were 244 respondents

\section{RESULTS AND DISCUSSION}

\subsection{Relationship between Organizational Culture and Teacher Performance}

Based on the results of hypothesis testing showed that there is a functional relationship between organizational culture and teacher performance with regression equation $\hat{Y}=100.278+0.146 \mathrm{X}_{1}$ with a correlation coefficient of 0.328 indicates that an increase in the score of organizational culture will improve teacher performance. The coefficient of determination between organizational culture and teacher performance is $\left(\mathrm{r}_{\mathrm{y} 1}\right)^{2}=0.1074$. This means that $10.74 \%$ of teacher performance is the result of the workings of organizational culture, while $80.36 \%$ is contributed by other variables that have a relationship with improving teacher performance.

Table1: Linearity test and coefficient of correlation of Organizational Culture $\left(X_{1}\right)$ to Teacher Performance $(Y)$

\begin{tabular}{|c|c|c|c|c|c|}
\hline Observation & $\mathbf{R}$ & $\mathbf{R}^{\mathbf{2}}$ & $\mathbf{F}_{\text {-test }}$ & $\mathbf{F}_{\text {-tabel }} \boldsymbol{1}$ & \multirow{2}{*}{ Conclusion } \\
\cline { 1 - 4 } $\mathbf{N}$ & $\mathbf{R}_{\mathbf{x} 1}$ & $\mathrm{r}_{\mathbf{x} 1}^{2}$ & $\mathbf{F}_{\mathbf{x} 1}$ & 0.05 & \\
\cline { 1 - 3 } & 0.328 & 0.1074 & 0.670 & 1.579 & Significant/Linear \\
\hline
\end{tabular}

Some of the results of previous studies have proven that organizational culture has a positive relationship with teacher performance, one of which is Hosseinkhanzadeh (2013), giving the conclusion that there is a significant positive relationship $(\mathrm{r}=0.637 \mathrm{p}<0.05)$ between an organizational culture with performance. The higher the organizational culture is predicted, the higher the level of individual performance. There is a very significant positive direct effect between organizational culture and performance.

Based on qualitative research, the results of the analysis of interviews, observation and documentation in three Private High Schools in South Tangerang City, it can be seen that the moderate relationship between organizational culture and teacher performance. This explains the strengthening of quantitative research results of hypothesis testing which states that there is a functional relationship between organizational culture and the performance of teachers who have a very significant regression and show that an increase in organizational culture scores will improve teacher performance.

Based on the results of the analysis using Scientific Identification Theory for Operation Research in Education Management (Hadhiedinata,2017) on the relationship between organizational culture with the teacher's performance an illustration is obtained that 1) the values dimension which includes indicators: a) The most important values that are understood together have a significance of $21 \%$ with an empirical finding of an average of $3.85, \mathrm{~b}$ ) Norms and standards behavior in work has a consequence of $20 \%$ with an average empirical result of 3.75. 2) Basic Assumption Pattern Dimensions which include indicators: a) Relationship with environment has $12 \%$ significance with empirical results average of 3.92 , b) Relationship between individuals has an essential meaning of 
Teacher Performance Improvement through Development of Organizational Culture, Work-Discipline, and Job Satisfaction

$15 \%$ with average empirical findings 3.9 , c) The view of humanity has a vital meaning of $11.50 \%$ with the result of 2.98. 3) Behavioral Pattern Dimensions which include indicators: a) The methods and technology used in work have a significance of $11.36 \%$ with an empirical finding of an average of 3.68, b) Real behavior patterns have an essential meaning of $9 \%$ with empirical results averaged 3.92. All the indicators on the performance of teachers mean that the stronger the organizational culture eat the higher performance of teachers

\subsection{Relationships between Discipline Working with Teacher Performance}

Based on hypothesis testing results show that there is a functional relationship between the discipline of work with teacher performance regression equation $\mathrm{Y}=96.043+0.229 \mathrm{X}_{2}$ with the coefficient of determination between work discipline and teacher performance is $\left(\mathrm{r}_{\mathrm{y} 2}\right)^{2}=0.633$. This means that $63.30 \%$ of teacher performance is a result of the workings of work discipline, while $37.70 \%$ is contributed by other variables that have a relationship with improving teacher performance.

Table2: Linearity test and coefficient of correlation of Discipline Working $\left(X_{2}\right)$ to Teacher Performance $(Y)$

\begin{tabular}{|c|c|c|c|c|c|}
\hline Observation & $\mathbf{R}$ & $\mathbf{R}^{2}$ & $\mathbf{F}_{\text {-test }}$ & $\mathbf{F}_{\text {-tabel }} \alpha$ & \multirow{2}{*}{ Conclusion } \\
\cline { 1 - 4 } $\mathbf{N}$ & $\mathbf{R}_{\mathbf{x} 2}$ & $\mathrm{r}_{\mathbf{x} 2}^{2}$ & $\mathbf{F}_{\mathbf{x} 2}$ & 0.05 & \\
\hline 244 & 0.796 & 0.633 & 0.710 & 1.604 & Significant/Linear \\
\cline { 1 - 3 }
\end{tabular}

Some of the results of previous studies have proven that organizational culture has a positive relationship with teacher performance, one of which is the research of Sofyan (2013) giving the conclusion that there is a significant positive relationship $(\mathrm{r}=0.607 \mathrm{p}<0.05)$ between work discipline and performance. The higher a person's work discipline is predicted to be the higher the performance. A strong work discipline will affect a significant increase in performance, this is indicated by the correlation coefficient of 0.607 , and the coefficient of determination is $36.84 \%$.

Based on qualitative research, the results of the analysis of interviews, observation and documentation in three Private High Schools in South Tangerang City, it can be seen that the moderate relationship between organizational culture and teacher performance. This explains the strengthening of quantitative research results of hypothesis testing which states that there is a functional relationship between organizational culture and the production of teachers who have a very significant regression and show that an increase in corporate culture scores will improve teacher performance.

Based on the results of the analysis using SITOREM (Scientific Identification Theory for Operation Research in Education Management) on the relationship between work discipline with the teacher's performance is illustrated that 1) The Dimension of Organizational Regulation which includes indicators: a) Provisions that foster awareness of employees to work orderly and prioritize safety have a significance of $17.52 \%$ with an empirical finding of an average of 3.76. b) Determination of sanctions for violations of employee behavior has an essential meaning of $17.32 \%$ with a practical result of an average of 3.72. 2) Implementation Dimensions and Supervision of regulations which include indicators: a). Ratings(assessment)on the behavior of employees based on the rules of discipline has an essential meaning of $16.91 \%$ with an average empirical finding 3.63, b) Systems and procedures for application of reprimand and sanctions for breach of discipline have significance for 14.24\% with empirical results averaging 3.67. 3) Organization Membership Compliance / Compliance Dimensions which include indicators: a) Setting sanctions for violations of employee behavior has an essential meaning of $17.32 \%$ with an empirical finding of an average of 3.72 , b) Procedure for providing reinforcement (positive reinforcement) to actions that change due to discipline / sanctions discipline has an significance of $16.71 \%$ with an empirical finding of an average of 3.59 . All of these indicators affect teacher performance, which means that the stronger the work discipline, the higher the teacher's performance.

\subsection{Relationship between Job Satisfaction (X3) with Teacher Performance (Y)}

From the results of hypothesis testing shows that there is a functional relationship between job satisfaction and teacher performance, the regression equation $\hat{Y}=77.387+0.425 \mathrm{X}_{3}$ with the value of the coefficient of determination between job satisfaction and performance the teacher is $\left(r_{y 3}\right)=0.6387$. This means that $63.87 \%$ of teacher performance is the result of working job satisfaction, while the remaining $36.13 \%$ is contributed by other variables that have a relationship with improving teacher performance. 
Teacher Performance Improvement through Development of Organizational Culture, Work-Discipline, and Job Satisfaction

Table3: Linearity test and coefficient of correlation of Job Satisfaction $\left(X_{3}\right)$ to Teacher Performance $(Y)$

\begin{tabular}{|c|c|c|c|c|c|}
\hline Observation & $\mathbf{R}$ & $\mathbf{R}^{2}$ & $\mathbf{F}_{\text {-test }}$ & $\mathbf{F}_{\text {-tabel }} \alpha$ & \multirow{2}{*}{ Conclusion } \\
\cline { 1 - 4 } $\mathbf{N}$ & $\mathbf{R}_{\mathbf{x} 3}$ & $\mathrm{r}_{\mathbf{x} 3}^{2}$ & $\mathbf{F}_{\mathbf{x} 3}$ & 0.05 & \\
\hline 244 & 0.6387 & 0.799 & 0.670 & 1.579 & Significant/Linear \\
\cline { 1 - 3 }
\end{tabular}

The results of previous studies have also proven that job satisfaction has a positive relationship with job satisfaction, one of which is the research from Arifin (2015) giving the conclusion that there is a significant positive relationship $(\mathrm{r}=0.540 \mathrm{p}<0.05)$ between job satisfaction with teacher performance. The higher the level of job satisfaction is predicted to be the higher the level of teacher performance. A strong work discipline will affect a significant increase in performance, and this is indicated by a correlation coefficient of 0.540 and a coefficient of determination of $29.16 \%$.

Based on the results of the analysis using SITOREM (Scientific Identification Theory for Operation Research in Education Management) on the relationship between job satisfaction and the teacher's performance shows that 1) the work itself has an importance of $20 \%$ with empirical findings averaging $4.61,2$ ) rewards related to assignments have an essential meaning of $15 \%$ with empirical results on average $4.54,3$ ) the opportunity for self-promotion and development has a significance of $15 \%$ with an empirical finding of an average of $4.42,4)$ the relationship between coworkers and superiors has a significance of $25 \%$ with an average empirical result of $4.48,5$ ) a sense of justice the relation with the task has an importance of $20 \%$ with an empirical finding averaging 4.61 , and 6) supervision from superiors has an essential meaning of $20 \%$ with an observed result of an average of 4.54. All of these indicators affect teacher performance, which means that the stronger job satisfaction, the higher the teacher's performance.

Based on SITOREM analysis, priorities on each indicator are shown in Figure 1.
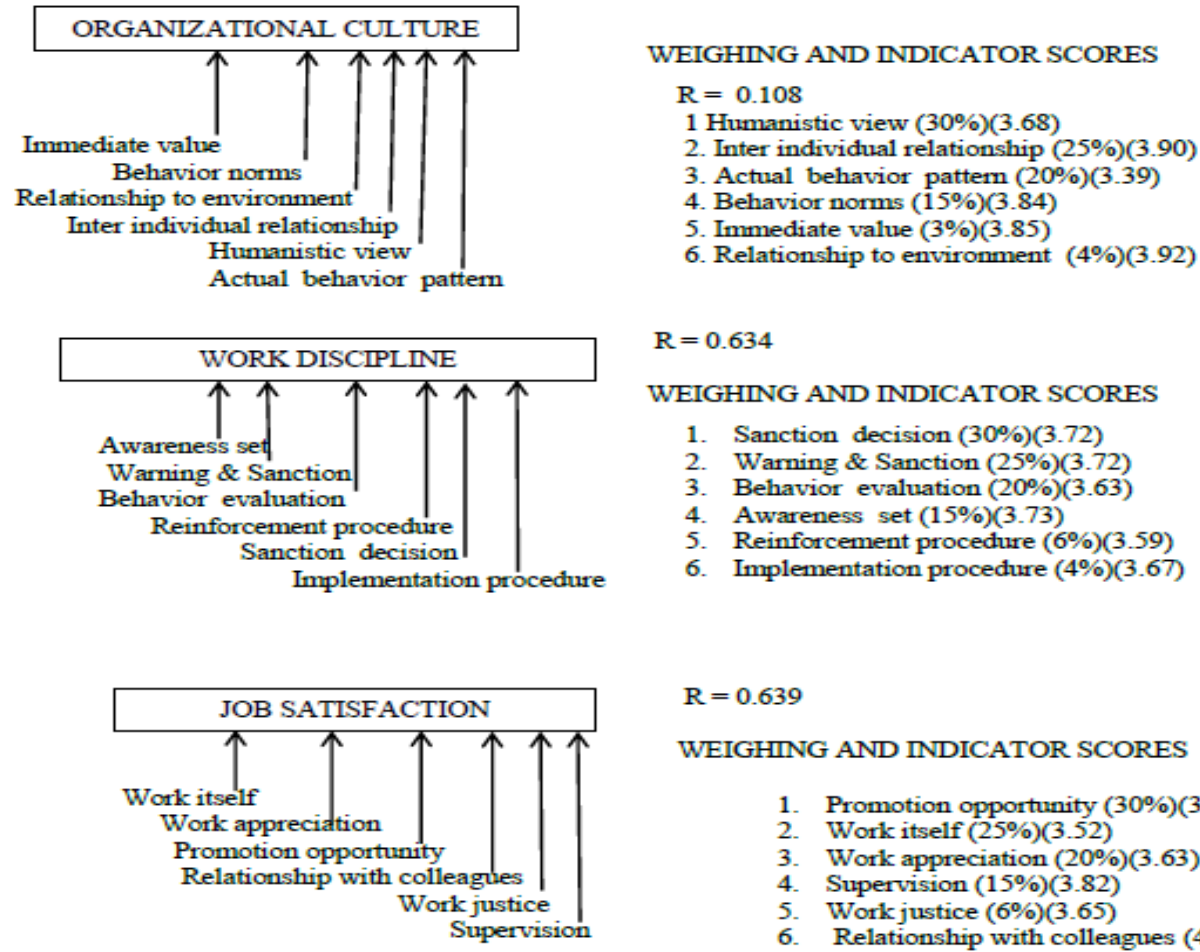

$R=0.639$

WEIGHING AND INDICATOR SCORES
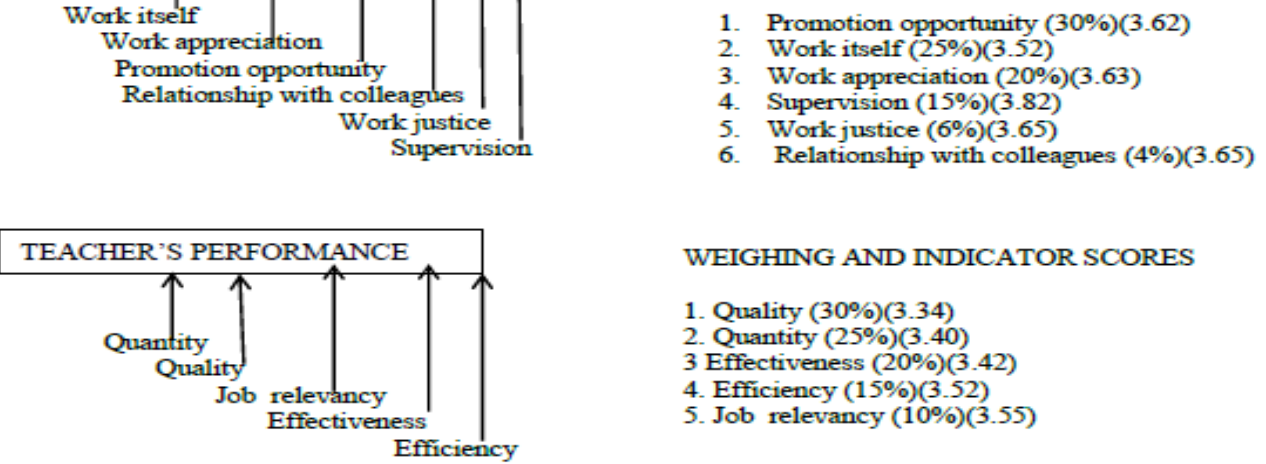

WEIGHING AND INDICATOR SCORES

1. Quality (30\%)(3.34)

2. Quantity $(25 \%)(3.40)$

3 Effectiveness (20\%)(3.42)

4. Efficiency $(15 \%)(3.52)$

5. Job relevancy $(10 \%)(3.55)$

Figure1: SITOREM Analysis

Since none of the indicators hasvalue above 4 , it is concluded that none of the indicators must be retained. The improvement based on the importance is ranked below: 
Teacher Performance Improvement through Development of Organizational Culture, Work-Discipline, and Job Satisfaction

- Promotion opportunity

- Work itself

- Work appreciation

- Supervision

- Work justice

- Relationship with colleagues

- Sanction decision

- Warning \& Sanction

- Behavior evaluation

- Awareness set

- Reinforcement procedure

- Implementation procedure

- Humanistic view

- Inter-individual relationship

- Actual behavior pattern

- Behavior norms

- Immediate value

- Relationship to environment

- Quality

- Quantity

- Effectiveness

- Efficiency

- Job relevancy

\subsection{The Relationship between Organizational Culture (X1), Work-Discipline (X2) and Job} Satisfaction (X3) Together with Teacher Performance (Y)

From the results of hypothesis testing shows that there is a functional relationship between organizational culture, work discipline and job satisfaction together with teacher performance indicated by the regression equation $\hat{Y}=88.719+0.156 \mathrm{X}_{1}+0.029 \mathrm{X}_{2}+0.053 \mathrm{X}_{3}$ withF value calculated $=36.165>\mathrm{F}_{\text {table }}(\alpha=0.05)=3.880$ and $\mathrm{F}_{\text {table }}(\alpha=0.01)=6.943$ which means that the regression significance is very significant. The multiple correlation coefficient between organizational culture, work discipline and job satisfaction together with teacher performance is 0.555 indicating that each increase in organizational culture scores, work discipline, and job satisfaction together will improve teacher performance. The results obtained for the coefficient of determination $\left(\mathrm{r}_{\mathrm{y} 123}\right)^{2}$ from the correlation between organizational culture, work discipline and job satisfaction together with teacher performance amounted to 0.305 . This means that $30.50 \%$ of teacher performance is the result of the workings of organizational culture, work discipline, and job satisfaction together, while the remaining $69.50 \%$ is contributed by other variables that have a relationship with improving teacher performance.

The trend that can be seen from the results of this study is the correlation between organizational culture and teacher performance ie $r_{\mathrm{y} 1}=0.331$ when compared to the relationship between work discipline and teacher performance ie $\mathrm{r}_{\mathrm{y} 2}=0.162$ and the relationship between job satisfaction and teacher performance $\mathrm{r}_{\mathrm{y} 3}=0.782$ indicating that the organizational culture is above the two independent variables, but each or together these three variables can contribute to improving teacher performance.

The results of this study indicate that organizational culture is a determining factor for the realization of the goals and mission of education, with schools continuing to invite all school members to work together to make changes in a better direction, innovate to create, renew and perfect the organizational management system in schools. Organizational culture factors also determine the success of the education system in schools. High dedication, seriousness, and discipline to work and want to get an 
Teacher Performance Improvement through Development of Organizational Culture, Work-Discipline, and Job Satisfaction

award are manifested in the work implementation oriented towards optimal standardized processes and work results. All of this results in a conducive working atmosphere and effectively creates comfort and harmony in the school community with their respective duties and functions.

\section{CONCLUSION}

There is a positive relationship between Organizational Culture and Teacher Performance of $10.74 \%$. This positive relationship is reinforced by the results of qualitative research. Thus it can be stated that the higher the Organizational Culture, the higher the Teacher's Performance. There is a positive relationship between Work Discipline and Teacher Performance of $63.30 \%$. Thus it can be stated that the higher the Work Discipline, the higher the Teacher's Performance. There is a positive relationship between Job Satisfaction and Teacher Performance of $63.87 \%$. Thus it can be stated that the higher Job Satisfaction, the higher Teacher Performance. There is a very significant positive relationship between Organizational Culture, and Job Satisfaction together with Teacher Performance of $30.50 \%$. All variables of this relationship are strengthened by the results of qualitative research. Thus the higher the Organizational Culture, Work-Discipline and Job Satisfaction together can improve Teacher Performance in Private High School teachers in South Tangerang City.

\section{REFERENCE}

[1] Arifin, H. Muhammad. "The Influence of Competence, Motivation, and Organisational Culture to High School Teacher Job Satisfaction and Performance." International Education Studies 8, no. 1 (2015): 3845.Alvesson Mats. Understanding organizational culture. Sage, 2012.

[2] Bolkan, San, Alan K. Goodboy, and Darrin J. Griffin. "Teacher leadership and intellectual stimulation: Improving students' approaches to studying through intrinsic motivation." Communication Research Reports 28, no. 4 (2011): 337-346.

[3] Griffin, Marie L., Nancy L. Hogan, Eric G. Lambert, Kasey A. Tucker-Gail, and David N. Baker."Job involvement, job stress, job satisfaction, and organizational commitment and the burnout of correctional staff." Criminal Justice and Behavior37, no. 2 (2010): 239-255.

[4] Hosseinkhanzadeh, Abbas Ali, Ahmad Hosseinkhanzadeh, and TaiebehYeganeh. "Investigate the relationship between job satisfaction and organizational culture among teachers." Procedia-Social and Behavioral Sciences 84 (2013): 832-836.

[5] Hardhienata, S. The development of scientific identification theory to conduct operation research in education management, IOP Conf. Series: Materials Science and Engineering 166 (2017) 012007 doi:10. 1088 / 1757 - 899X / 166 / I / 012007.

[6] Olina, Zane, and Howard J. Sullivan."Student self-evaluation, teacher evaluation, and learner performance." Educational Technology Research and Development 52, no. 3 (2004): 5-22.

[7] Schein, Edgar H. Organizational culture and leadership.Vol. 2.John Wiley \& Sons, 2010.

[8] Sofyan, Muhammad, Abdul Rahman, MuhJobharBima, and SyamsuNujum. "The Effect Of Career Development And Working Discipline Towards Working Satisfaction And Employee Performance In The Regional Office Of Ministry Of Religious Affairs In South Sulawesi." International Journal of Scientific and Technology Research 5, no. 3 (2016): 51-57.

[9] Suwati, Suwati, Maria Magdalena Minarsih, and Edward Gagah. "Influence of motivation work, career development and cultural organization on the job satisfaction and implications on the performance of employees (Case on BABINMINVETCADDAM IV/Diponegoro)." Journal of Management 2, no.2 (2016).

[10] Terrell, Steven R. "Mixed-methods research methodologies." The qualitative report 17, no. 1 (2012): 254-280.

Citation: Muljadi, Hadhienata S, Adhie E Yusuf. "Teacher Performance Improvement through Development of Organizational Culture, Work-Discipline, and Job Satisfaction" International Journal of Managerial Studies and Research (IJMSR), vol 7, no. 4, 2019, pp. 71-77. doi:http://dx.doi.org/10.20431/ 23490349.0704010.

Copyright: (C) 2019 Authors. This is an open-access article distributed under the terms of the Creative Commons Attribution License, which permits unrestricted use, distribution, and reproduction in any medium, provided the original author and source are credited. 